\title{
Kendala Pengendalian Pencemaran Total Suspended Solid dan Phosphat di Sub Das Tlaga Ria Sentani Pasca Banjir Bandang
}

\author{
Auldry F. Walukow ${ }^{1^{*}}$, Triwiyono ${ }^{2}$, Albert Lumbu ${ }^{3}$ \\ ${ }^{1,2,3}$ Staf Pengajar Universitas Cenderawasih Jayapura - Papua \\ *Koresponden E-mail: walukow.auldry@gmail.com
}

(Diterima 27 Maret 2021 |Disetujui 16 Juli 2021|Diterbitkan 19 Juli 2021)

\begin{abstract}
The problem that occurs in Lake Sentani is that it has been contaminated by parameters of TSS, $B O D, P b, C u$, and DO respectively with values of $76 \mathrm{mg} / \mathrm{L}, 4.63 \mathrm{mg} / \mathrm{L}, 0.035 \mathrm{mg} / \mathrm{L}, 0.03 \mathrm{mg} / \mathrm{L}$, and $5.72 \mathrm{mg} / \mathrm{L}$ because these parameters have exceeded the quality standard according to environmental regulations. This study aims to determine the assimilation capacity of TSS and PO4 parameters and analyze pollution control models in the Tlaga Ria sub-watershed. The research method used to determine the assimilation capacity is a linear regression equation and in analyzing the pollution control model the interpretative structural modeling method is used. The results showed that the TSS assimilation capacity value in Lake Sentani was -12,700 tons/month. The value of water quality in Lake Sentani is above the value of the assimilation capacity, this shows that Lake Sentani has been polluted by TSS parameters. Meanwhile, the value of PO4 parameter assimilation capacity is 44.36 tons/month and since 2016 Lake Sentani has been unable to conduct self purification. The key elements of the Sentani Lake pollution control constraints in the Tlaga Ria watershed are weak implementation of environmental regulations, differences in objectives among stakeholders, differences in objectives between administrative areas, weak support of business owners, conflict of interests, and weak enforcement of regulations.
\end{abstract}

Keywords: Assimilation capacity, Control model, Pollution, Lake Sentani, Tlaga Ria

\section{PENDAHULUAN}

Danau Sentani terletak di Kabupaten Jayapura, pada posisi $2^{\circ} 33^{\prime}-2^{\circ} 41^{\prime}$ LS dan $140^{\circ} 23^{\prime}-140^{\circ} 38^{\prime}$ BT. Danau ini terletak pada ketinggian $70-90 \mathrm{~m} \mathrm{dpl}$ dengan luas 9.360 Ha (Walukow, 2012). Berdasarkan tipologinya, Danau Sentani merupakan tipe danau Landslide yaitu perairan tergenang yang terbentuk akibat pergeseran lahan yang membentuk basin, sehingga terbentuk tipe danau yang curam dan dikelilingi oleh bukit - bukit kecil yang terjal dan berlekuk-lekuk seperti teluk. Secara umum, kondisi danau mengarah ke kondisi eutrofik.

Daerah aliran sungai (DAS) Danau Sentani memiliki 11 sub DAS yang sungai-sungainya bermuara ke Danau Sentani. Sub DAS Tlagaria terdapat pada Sungai Tlagaria dengan panjang sungai $1482,330 \mathrm{~m}$ dan luas 2012,259 Ha. Laju erosi di sub DAS Tlaga Ria terus meningkat dari 44518,907 $\mathrm{m}^{3} /$ tahun menjadi $48790,565 \mathrm{~m}^{3} /$ tahun dan debit sedimen juga terus meningkat dari $0,0014 \mathrm{~m}^{3} /$ tahun menjadi $0,0016 \mathrm{~m}^{3} /$ tahun. Danau Sentani telah tercemar oleh parameter TSS $76 \mathrm{mg} / \mathrm{L}$, BOD 4,63 $\mathrm{mg} / \mathrm{L}, \mathrm{Pb} 0,035 \mathrm{mg} / \mathrm{L}, \mathrm{Cu} 0,03 \mathrm{mg} / \mathrm{L}$ dan DO 5,72 $\mathrm{mg} / \mathrm{L}$ oleh karena parameter - parameter tersebut tidak memenuhi standar baku mutu yang ditetapkan menurut peraturan menteri lingkungan hidup (PP No 22 Tahun 2021, Kapisa, 2017 dan Badan Lingkugan Hidup, 2016).
Beberapa penelitian tentang beban pencemaran sungai - sungai yang masuk ke Danau Sentani menyimpulkan bahwa beban pencemaran $\mathrm{Cu}$ di sungai Jembatan dua meningkat dari 0,01 ton/bulan menjadi 0,08 ton/bulan sejak tahun 2012 sampai 2014 (Walukow, 2016, 2021a), beban pencemaran TDS meningkat dari 263,09 ton/bulan menjadi 287,70 ton/bulan (Walukow, 2008, 2021b). Begitu pula beban pencemaran Fosfat di Sungai Flafouw meningkat dari 0,26 ton/bulan menjadi 1,71 ton/bulan pada tahun 2005 sampai 2007 (Walukow, 2010a, 2010b). Peningkatan beban pencemaran di sungai - sungai yang masuk ke Danau Sentani tersebut telah mengakibatkan peningkatan sedimen di Danau Sentani. Walukow, (2017a, 2017b) juga telah meneliti pencemaran $\mathrm{Pb}$ dalam sedimen di Danau Sentani, dimana hasil penelitian menunjukkan bahwa konsentrasi $\mathrm{Pb}$ dalam sedimen sekitar $28 \mathrm{mg} / \mathrm{kg}$ sampai $40 \mathrm{mg} / \mathrm{kg}$.

Pencemaran air yang terjadi di Danau Sentani, Propinsi Papua juga sering terjadi pada danau di luar negeri. Penelitian pencemaran Danau di luar negeri seperti Duan et al., (2016) menyebutkan bahwa terdapat lima sumber pencemaran potensial di danau Poyang, China yaitu pencemaran nutrisi, pencemaran organik yang mengonsumsi oksigen, pencemaran kimia fluor, pencemaran logam berat, dan pencemaran alam. Bahteria et al., (2016) menyimpulkan bahwa pertumbuhan penduduk yang terus meningkat, urbanisasi dan modernisasi menimbulkan masalah pembuangan limbah dan akhirnya mengakibatkan kontaminasi pada air permukaan sep- 
erti danau. Pencemaran limbah ke danau secara terus menerus mengakibatkan daya dukung dan daya tampung danau akan terlampaui. Zhao, et al., (2010) mengkaji bahwa Danau Baiyangdian di Cina memiliki daya tampung maksimum dimana toleransi maksimum yang dikeluarkan dari total fosfor dan nitrogen ke Danau Baiyangdian adalah 10 ton / tahun dan 437,5 ton / tahun, dimana total $\mathrm{P}$ dan Total $\mathrm{N}$ menjadi pencemar utama yang menyebabkan terjadinya eutrofikasi pada danau tersebut. Selain Total $\mathrm{P}$ dan Total $\mathrm{N}$ dari sungai Tapis, sumber - sumber pencemar yang mencemari danau juga berasal dari lapisan atmosfer. Cheruiyot et al., (2014) telah meneliti bahwa endapan bahan di atomosfer memberikan konstribusi yang signifikan (30\%-80\%) terhadap Total $\mathrm{N}$ dan Total P ke Danau Victoria di Afrika Timur. Pada penelitian - penelitian yang dilakukan di luar negeri tersebut belum meneliti tentang kapasitas asimilasi dan model pengendalian pencemaran. Oleh sebab itu keterbaruan dalam penelitian ini adalah menganalisis kapasitas asimilasi dan model pengendalian pencemaran di Sub DAS Tlaga Ria menggunakan metode Interpretative structural modelling (ISM). Keunggulan metode ISM ini adalah dapat menganalisis elemen kunci dan kekuatan penggerak pengendalian pencemaran di Danau Sentani khususnya di sub Daerah aliran sungai Tlaga Ria
(Marimin, 2004). Penelitian ini bertujuan menentukan kapasitas asimilasi parameter TSS dan $\mathrm{PO}_{4}$ serta menganalisis model pengendalian pencemaran di sub DAS Tlaga Ria.

\section{BAHAN DAN METODE}

Metode penelitian yang digunakan adalah metode survey dengan pendekatan deskriptif kualitatif. Pengambilan sampel pada tanggal 23 Mei 2019. Penelitian ini dilaksanakan di area sub DAS Tlaga Ria seperti Gambar 1. Metode penentuan stasiun dalam pengambilan sampel air dilakukan dengan purposive sampling yaitu penentuan stasiun pengamatan dilakukan dengan memperhatikan berbagai pertimbangan kondisi dan keadaan tempat penelitian seperti kondisi aktivitas di darat, dan inlet sungai yang diduga berpengaruh terhadap kualitas air sungai di DAS Tlaga Ria. Bahan yang digunakan untuk memperoleh data elemen kunci model pengendalian $\mathrm{Da}$ nau menggunakan kuesioner Intrerprertative structural modelling dan jawaban responden pakar. Metode analisis sampel untuk parameter kimia TSS dan $\mathrm{PO}_{4}$ adalah analisis laboratorium dengan menggunakan metode Spectometry dengan nomor SNI 06-24121991.

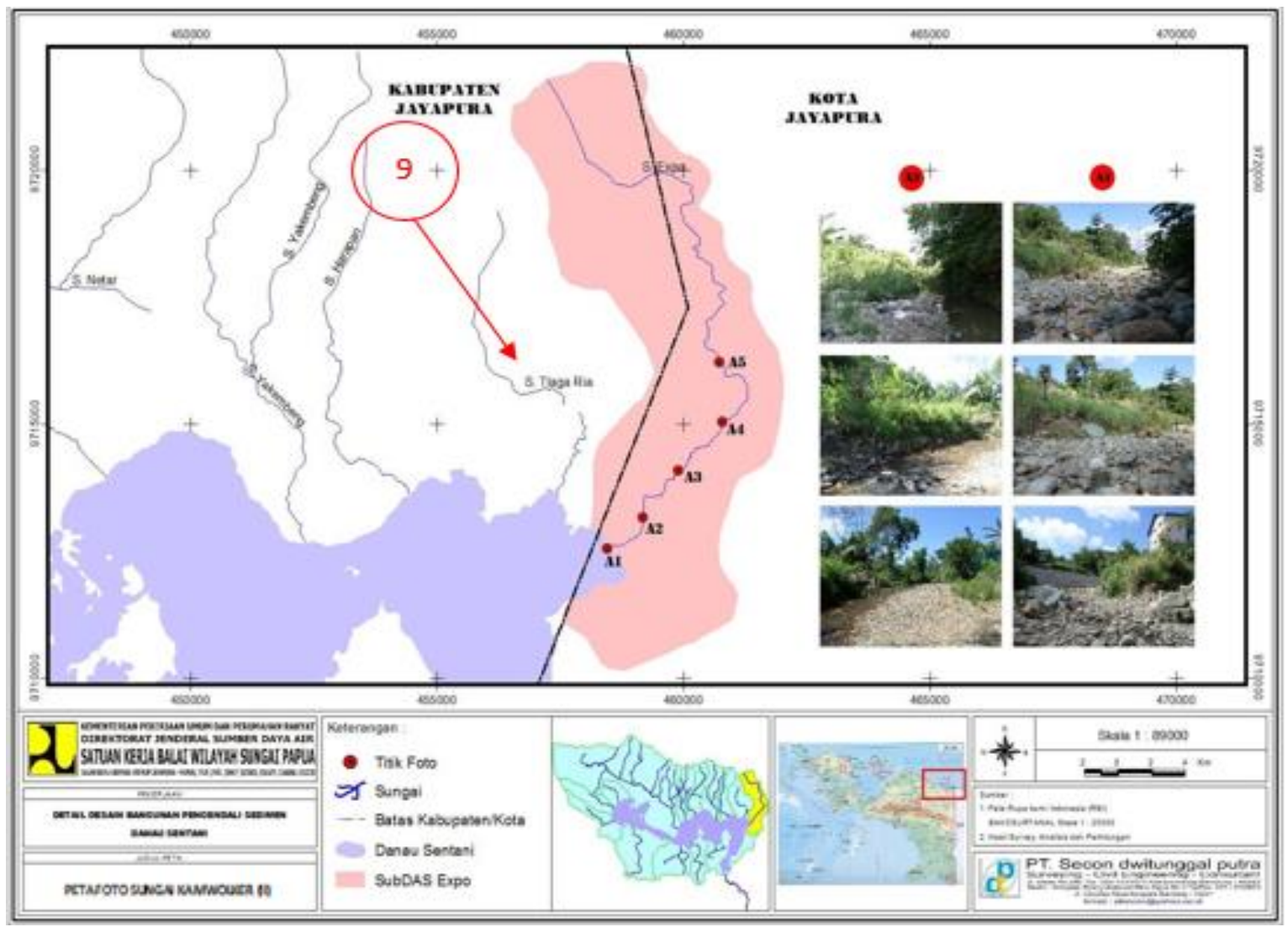

Gambar 1. Lokasi Penelitian 
Langkah - Langkah Analisis Kapasitas Asimilasi :

Menghitung Beban Pencemaran :

$\mathrm{X}=\mathrm{KQC}$

$\mathrm{X}=$ Beban Pencemaran (ton/bulan)

$\mathrm{K}=$ konstanta $(2,592)$

$\mathrm{Q}=$ Debit Sungai (liter/detik)

$\mathrm{C}=$ konsentrasi parameter kualitas air sungai $(\mathrm{mg} / \mathrm{L})$

Menghitung Persamaan regresi untuk menentukan kapasitas asimilasi :

$\mathrm{Y}=\mathrm{a}+\mathrm{bX}$

$\mathrm{X}=$ Beban Pencemaran (ton/bulan)

$\mathrm{Y}=$ Konsentrasi parameter kualitas air danau $(\mathrm{mg} / \mathrm{L})$

Menghitung Kapasitas Asimilasi $\left(\mathrm{X}_{1}\right)$ :

$\mathrm{Y}_{1}=\mathrm{a}+\mathrm{b} \mathrm{X}_{1}$

$\mathrm{Y}_{1}=$ Baku mutu parameter kualitas air danau $(\mathrm{mg} / \mathrm{L})$

$\mathrm{X}_{1}=$ Kapasitas Asimilasi (ton/bulan)

Jika dalam perhitungan diperoleh posisi nilai beban pencemaran berada di sebelah kanan nilai kapasitas asimilasi, maka hal ini berarti perairan tersebut tidak mampu melakukan self purification.

Langkah - Langkah Metode Interpretative Structural Modelling:

Identifikasi Elemen dan Sub Elemen :
Dalam hal ini elemen yang diidentifikasi adalah elemen kendala, dan hasil identifikasi sub elemen terdapat 13 sub elemen kendala yaitu : Lemahnya Implementasi Regulasi lingkungan, Perbedaan tujuan antar stakeholder, Perbedaan tujuan antar wilayah administrasi, Lemahnya Implementasi Projek Lingkungan, Lemahnya Konsistensi kerjasama , Lemahnya etika lingkungan, Lemahnya Koordinasi antar instansi, Rendahnya Kualitas dan kuantitas SDM, Lemahnya Pengelolaan Lingkungan, Lemahnya dukungan pemilik usaha, Konflik Kepentingan, Lemahnya Penegakan Peraturan, dan Implementasi Kebijakan Yang Tidak Efektif

\section{Menganlisis Hubungan Kontekstual :}

Jenis hubungan kontekstual yang digunakan adalah hubungan comparative yakni A lebih penting dari pada B yang dinyatakan dengan simbol sebagai berikut :

V jika $e_{i j}=1$ dan $e_{j i}=0, A$ jika $e_{i j}=0$ dan $e_{j i}=1, X$ jika $e_{i j}=1$ dan $e_{j i}=1, O$ jika $e_{i j}=0$ dan $e_{j i}=0$

\section{Mengisi Matrik Structural self interaction matrix (SSIM):}

Responden mengisi matrik SSIM dengan symbol (V,A,X,O), dalam hal ini terdapat 13 sub elemen kendala, seperti pada Tabel 1.

Tabel 1. Matrik Structural self interaction matrix

\begin{tabular}{|c|c|c|c|c|c|c|c|c|c|c|c|c|c|}
\hline \multirow{2}{*}{$\begin{array}{l}\text { Sub } \\
\text { Elemen } \\
\mathrm{Ke}\end{array}$} & \multicolumn{12}{|c|}{ Sub elemen aktivitas ke- } & \\
\hline & 13 & 12 & 11 & 10 & 9 & 8 & 7 & 6 & 5 & 4 & 3 & 2 & 1 \\
\hline 1 & & & & & & & & & & & & & \\
\hline 2 & & & & & & & & & & & & & \\
\hline 3 & & & & & & & & & & & & & \\
\hline 4 & & & & & & & & & & & & & \\
\hline 5 & & & & & & & & & & & & & \\
\hline 6 & & & & & & & & & & & & & \\
\hline 7 & & & & & & & & & & & & & \\
\hline 8 & & & & & & & & & & & & & \\
\hline 9 & & & & & & & & & & & & & \\
\hline 10 & & & & & & & & & & & & & \\
\hline 11 & & & & & & & & & & & & & \\
\hline 12 & & & & & & & & & & & & & \\
\hline 13 & & & & & & & & & & & & & \\
\hline
\end{tabular}

Menyusum Matrik reachability matrix (RM) :

Setelah Structural self interaction matrix (SSIM) terisi sesuai pendapat responden, maka simbol (V, A,
$\mathrm{X}, \mathrm{O})$ dapat digantikan dengan simbol (1 dan 0) dengan ketentuan yang ada sehingga dapat diketahui nilai dari hasil reachability matrix (RM), seperti pada Tabel 2. 
Tabel 2. Matrik reachability matrix

\begin{tabular}{|c|c|c|c|c|c|c|c|c|c|c|c|c|c|c|c|}
\hline $\begin{array}{l}\text { Sub } \\
\text { Elemen } \\
\text { Kendala }\end{array}$ & 1 & 2 & 3 & 4 & 5 & 6 & 7 & 8 & 9 & 10 & 11 & 12 & 13 & DP & $\mathrm{R}$ \\
\hline 1 & & & & & & & & & & & & & & & \\
\hline 2 & & & & & & & & & & & & & & & \\
\hline 3 & & & & & & & & & & & & & & & \\
\hline 4 & & & & & & & & & & & & & & & \\
\hline 5 & & & & & & & & & & & & & & & \\
\hline 6 & & & & & & & & & & & & & & & \\
\hline 7 & & & & & & & & & & & & & & & \\
\hline 8 & & & & & & & & & & & & & & & \\
\hline 9 & & & & & & & & & & & & & & & \\
\hline 10 & & & & & & & & & & & & & & & \\
\hline 11 & & & & & & & & & & & & & & & \\
\hline 12 & & & & & & & & & & & & & & & \\
\hline 13 & & & & & & & & & & & & & & & \\
\hline
\end{tabular}

$\mathrm{D}=$ Driver Power, $\mathrm{R}=$ Rangking

\section{Membuat Grafik Hirarki}

Menentukan Driver Power dan Rangking, kemudian menyusun jumlah level dan hubungan antar level.

\section{HASIL DAN PEMBAHASAN}

\section{Kapasitas Asimilasi Danau Sentani Di Sub DAS Tlaga Ria}

Di Sub DAS Tlaga Ria tedapat Sungai Jembatan 2 (Sungai Hubai) dengan debit sungainya sebesar $110,416 \mathrm{~m}^{3} /$ detik. Nilai konsentrasi kualitas air TSS sebesar $52 \mathrm{mg} / \mathrm{L}$ hal ini menunjukkan bahwa Parameter TSS telah melebihi baku mutu menurut peraturan menteri lingkungan hidup yaitu $50 \mathrm{mg} / \mathrm{L}$ untuk klas II. Begitu pula nilai konsentrasi kualitas air $\mathrm{PO}_{4}$ sebesar $0,3 \mathrm{mg} / \mathrm{L}$ telah melebihi baku mutu yaitu 0,2 $\mathrm{mg} / \mathrm{L}$.

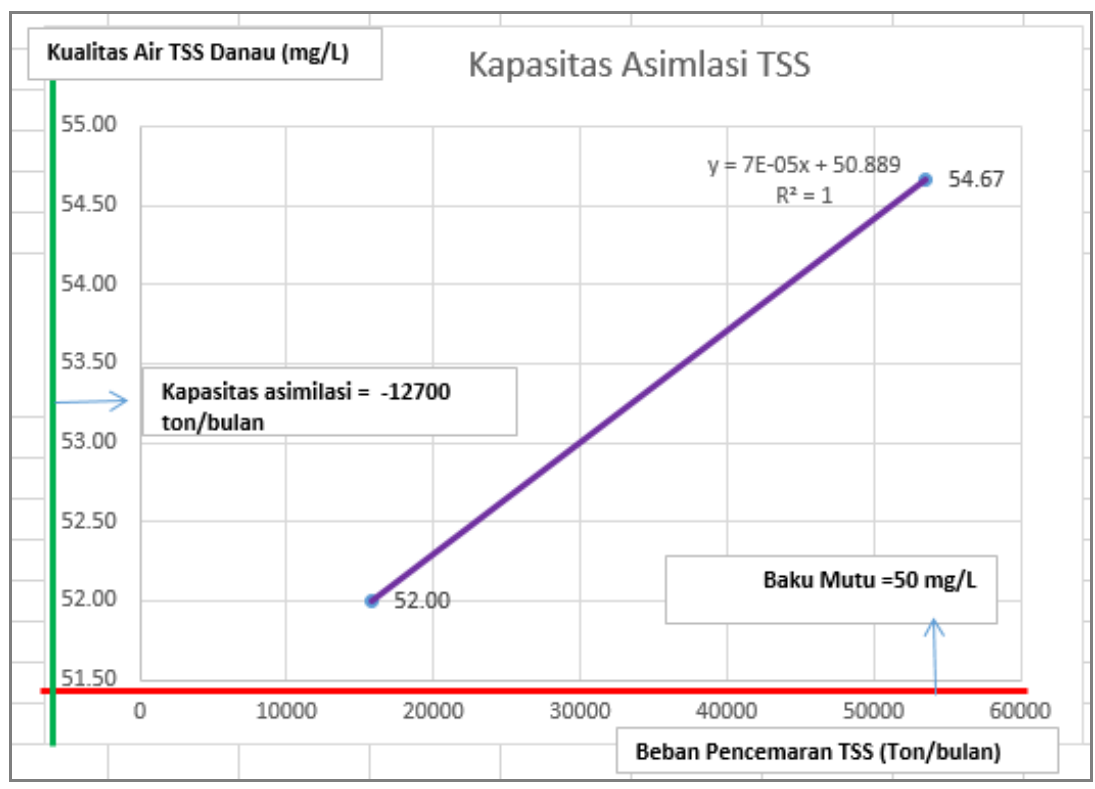

Gambar 2. Kapasitas Asimilasi TSS

Berdasarkan Gambar 2 nilai Kapasitas asimilasi TSS di Danau Sentani sebesar -12.700 ton/bulan. Pada Gambar 2 di atas terlihat bahwa nilai beban pencemaran di Danau Sentani berada di sebelah kanan nilai kapasitas asimilasi, hal ini menunjukkan bahwa danau Sentani telah tercemar oleh parameter TSS. Kondisi ini menunjukkan juga bahwa Danau Sentani tidak mampu melakukan self purification ter- hadap parameter TSS. Gambar 2 menunjukkan juga bahwa parameter TSS telah berada di atas baku mutu PP No 22 Tahun 2021. Peningkatan kosentrasi TSS dapat disebabkan factor alam seperti sedimentasi yang terjadi di hulu sungai dan limbah domestic yang merupakan sumber pencemar menyebar (nonpoint source) (Hamakonda, 2019). 


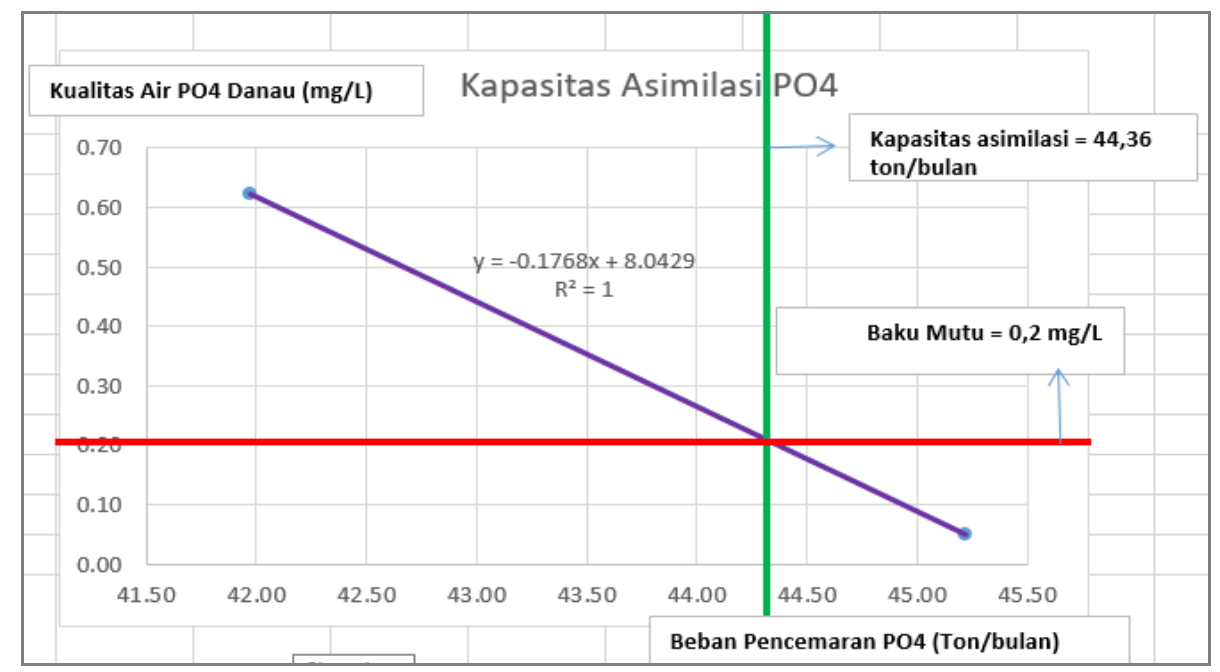

Gambar 3. Kapasitas Asimilasi PO4

Berdasarkan Gambar 3 menunjukkan nilai kapasitas asimilasi parameter $\mathrm{PO}_{4}$ sebesar 44,36 ton/bulan. Pada Gambar 3 di atas terlihat bahwa nilai beban pencemaran yang berada di sebelah kanan garis kapasitas asimilasi menunjukkan bahwa sejak tahun 2016 danau Sentani tidak mampu melakukan self purification. Sedangkan sebelum tahun 2013 Danau Sentani masih mampu melakukan self purification terhadap parameter $\mathrm{PO}_{4}$. Tingginya fosfat di perairan disebabkan oleh: daerah pemukiman membuang limbahnya ke sungai, difusi fosfat dari sedimen, dan limbah domestik yang mengandung detergen (Patty et al., 2015), (Patricia, 2018).

Kondisi nilai beban pencemaran parameter TSS di Danau Sentani berada di sebelah kanan nilai kapasitas asimilasi, hal ini menunjukkan bahwa danau Sentani telah tercemar. Hal ini berarti bahwa Danau Sentani tidak mampu melakukan self purification terhadap parameter TSS. Kondisi air danau Sentani berada pada titik saturasi karena walaupun berada di bawah baku mutu $\mathrm{PO}_{4}$ sebesar $0,2 \mathrm{mg} / \mathrm{L}$ namun air Danau tidak mampu melakukan self purification, oleh karena pada tahun 2013 nilai kualitas air berada di atas baku mutu namun air Danau masih mampu melakukan self purification. Artinya bahwa energy internal untuk mengasimilasi pencemar air danau telah habis atau telah berkurang kemampuannya. Self purification adalah kemampuan alamiah air danau untuk memulihkan diri sendiri sehingga kualitas air danau kembali memenuhi baku mutu. Namun dari hasil analisis menunjukkan bahwa kemampuan alamiah danau telah mencapai titik jenuh artinya tidak selamanya air danau akan mampu melakukan self purification. Hasil analisis ini menujukkan bahwa air danau Sentani tidak mampu melakukan self purification pada parameter TSS dan $\mathrm{PO}_{4}$ atau Danau Sentani tidak mampu lagi menerima pencemaran TSS dan $\mathrm{PO}_{4}$ agar terjadi self purificaton. Daya Dukung dan Daya Tampung danau Sentani dari segi parameter TSS dan $\mathrm{PO}_{4}$ adalah rendah. Hasil penelitian ini memperkuat temuan kajian Prasetia et al., (2021) bahwa di sekitar sub DAS Sentani telah tercemar ringan oleh karena ada beberapa parameter kimia telah melebihi baku mutu. Kondisi danau tercemar terjadi juga di Danau Matano yang disebabkan oleh parameter $\mathrm{PO}_{4}$ yang melebihi baku mutu sebagai akibat meningkatnya aktivitas di sekitar danau tersebut. Adanya dugaan pencemaran air disebabkan oleh pencemaran asal darat (land based pollution) berupa limbah pemukiman, industry, pertanian dan pertambangan (Sentosa et al., 2017).

Beban pencemaran TSS (Gambar 2) cenderung mengalami kenaikan mendadak, hal ini disebabkan oleh erosi tanah (Darmasusantini et al., 2015) dan (Pohan et al., 2016) . Erosi tanah di sub DAS Tlaga Ria karena 8,29\% CA Cycloop mengalami kerusakan. Hal ini menunjukkan aktivitas di hulu sub DAS Tlaga Ria berpengaruh terhadap turunnya kualitas air seperti TSS dan $\mathrm{PO}_{4}$. Menurut Riza et al.,(2015), Rahman et al., (2011), Andara et al., (2014) \& (Pohan et al., 2016) aktivitas di hilir yang berpotensi menurunkan kualitas air sungai dan danau seperti aktivitas MCK masyarakat, limbah kegiatan perikanan, aktivitas mencuci di sungai, aktivitas nelayan, pembuangan limbah cair (kegiatan pemukiman, hotel, Industri, restoran, dan rumah sakit). TSS yang tinggi meningkatkan kekeruhan, menurunkan kecerahan dan menghalangi penetrasi cahaya yangmasuk ke dalam perairan. Adanya aktivitas di sekitar hilir DAS Tlaga Ria maka dibutuhkan strategi seperti : menjaga Zona perlindungan sempadan sungai dan danau, meningkatkan pemantauan kualitas air sungai dan danau, pemberian izin pembuangan air limbah ke sungai dan danau harus memperhatikan kondisi daya tampung beban pencemaran sungai, dan melakukan penegakan hukum (Mahyudin, 2015).

Model Kendala Pengendalian Pencemaran Danau Sentani di Sub DAS Tlaga Ria:

Pada Gambar 4 terlihat bahwa yang menjadi elemen kunci pengendalian pencemaran Danau Sentani adalah sub elemen 1, 2, 3, 10, 11, dan 12 yang terletak pada level 5 . 


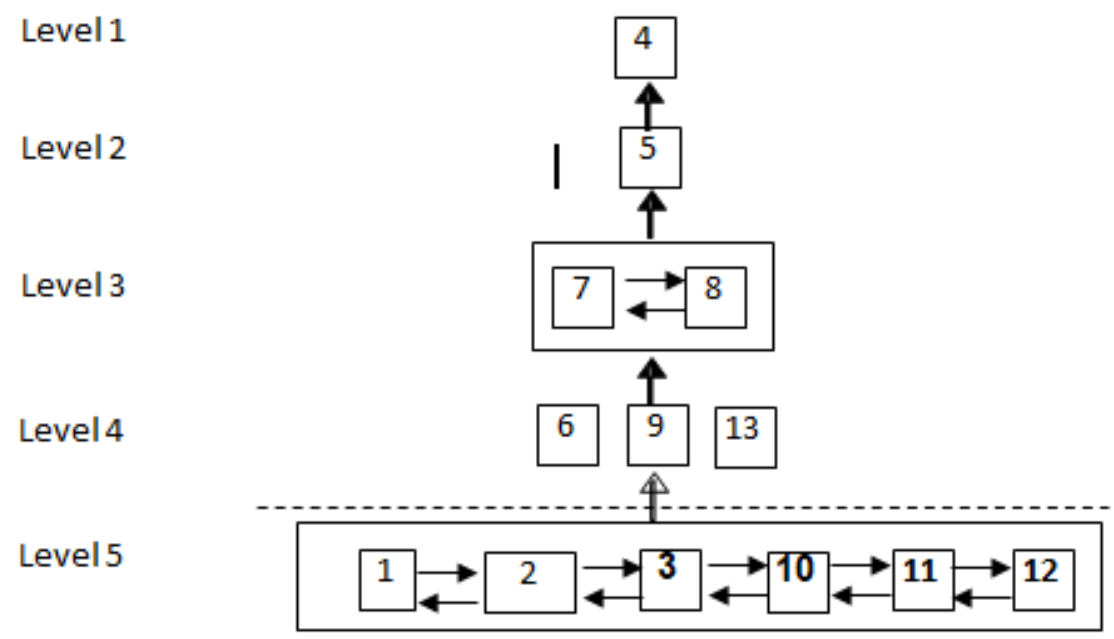

Gambar 4. Hasil Analisis ISM Pengendalian Danau Sentani

Hasil analisis menunjukkan bahwa ada $13 \mathrm{sub}$ elemen kendala pengendalian pencemaran danau Sentani seperti terlihat pada Tabel 3 .

Tabel 3. Sub elemen Kendala Pengendalian Pencemaran Danau Sentani

\begin{tabular}{ll}
\hline \multicolumn{3}{c}{ Subelemen } \\
\hline 1. & Lemahnya Implementasi Regulasi ling- \\
kungan & \\
2. Perbedaan tujuan antar stakeholder \\
3. Perbedaan tujuan antar wilayah administrasi \\
4. Lemahnya Implementasi Projek Ling- \\
5ungan \\
5. Lemahnya Konsistensi kerjasama \\
6. Lemahnya etika lingkungan \\
7. Lemahnya Koordinasi antar instansi \\
8. Rendahnya Kualitas dan kuantitas SDM \\
9. Lemahnya Pengelolaan Lingkungan \\
10. Lemahnya dukungan pemilik usaha \\
11. Konflik Kepentingan \\
12. Lemahnya Penegakan Peraturan \\
13. Implementasi Kebijakan Yang Tidak Efektif
\end{tabular}

Berdasarkan hirarki pada Gambar 4 dan Table 3 di atas terlihat bahwa kendala - kendala pengendalian pencemaran danau Sentani di sub DAS Tlaga Ria terletak pada level 5 yaitu Lemahnya Implementasi Regulasi lingkungan, Perbedaan tujuan antar stakeholder, Perbedaan tujuan antar wilayah administrasi, Lemahnya dukungan pemilik usaha, Konflik Kepentingan, dan Lemahnya Penegakan Peraturan. Lemahnya penegakkan regulasi di hulu DAS Sentani mengakibatkan kerusakan lahan seperti Lahan Kritis (Semak Belukar), Bekas Tebangan, Kebun Campuran Masyarakat dan galian C (Yulius, 2016). Sehingga kerusakan di DAS Sentani mengakibatkan luas kerusakan di CA Cycloop yang perlu direhabilitas sebesar 2611,46 ha atau $8,29 \%$ luas CA Cycloop perlu direhabilitasi. Hulu sub DAS Sentani merupakan daerah yang rawan perambahan yang dijadikan perkebunan milik masyarakat urban. Kerusakan di hulu DAS kemungkinan menjadi penyebab terjadinya banjir di hilir DAS Sentani. Hal ini sejalan dengan Nugraheni et al., (2016) yang menyebutkan banjir di hilir DAS Cikumpa pada tahun 2013 kemungkinan disebakan oleh kapasitas tampungan saluran yang kurang di bagian hilir DAS Cikumpa. Lahan Kritis di Cagar Cycloop dapat saja disebabkan oleh penggunaan lahan yang tidak memperhatikan usaha konservasi dan kelestarian tanah dan air. Lahan kritis tidak akan mampu lagi mengatur ketersediaan air serta tidak mampu berproduksi (Lestiana et.al., 2019). Oleh sebab itu upaya penegakan hukum yang harus diimplementasikan di DAS Sentani adalah pelarangan kegiatan di tempat yang tidak layak lingkungan dan perlunya sanksi hukum bagi yang melakukan pelanggaran (Walukow, 2010c).

Hasil analisis ditemukan bahwa kendala kendala penegendalian pencemaran di DAS Sentani khusunya sub DAS Tlaga Ria adalah Lemahnya Implementasi Regulasi lingkungan, Perbedaan tujuan antar stakeholder, Perbedaan tujuan antar wilayah administrasi, Lemahnya dukungan pemilik usaha, Konflik Kepentingan, dan Lemahnya Penegakan Peraturan (level 5) dan hal itu akan mempengaruhi Lemahnya etika lingkungan, Lemahnya pengelolaan lingkungan, dan Implementasi kebijakan tidak efektif (level 4). Selanjutnya lemahnya etika lingkungan, Lemahnya pengelolaan lingkungan, dan Implementasi kebijakan tidak efektif (Level 4) akan mempengaruhi Lemahnya Koordinasi antar instansi dan rendahnya kualitas dan kuantitas SDM (level 3). Begitu pula lemahnya koordinasi antar instansi, rendahnya kualitas dan kuantitas SDM (level 3) akan mempengaruhi lemahnya konsistensi kerja sama (level 2). Lemahnya konsistensi kerja sama (level 2) akhirnya akan mempengaruhi Lemahnya Implementasi Projek Lingkungan. Kajian ini sejalan dengan penelitian Siombo (2014) yang menyebutkan bahwa dalam pengendalian kerusakan lingkungan hidup dibutuhkan pelaksanaan pengawasan, pemantauan dan penegakan hukum administrasi maupun pidana 
yang tegas dan konsisten serta tidak diskriminatif. Lemahnya pengelolaan lingkungan perairan ditandai dengan lemahnya pengelolaan sampah, dan lemahnya pengelolaan limbah cair. Hal ini sejalan dengan Skenderovic et al., (2015) yang mengemukakan bahwa strategi pengelolaan sampah adalah tentang pengenalan mekanisme hukum formal, peningkatan pendidikan dan pelatihan mengelola limbah, dan pembentukan badan nasional yang bertanggung jawab dalam pendidikan dan pelatihan pengelolaan limbah. Manusia harus memiliki etika lingkungan agar pencemaran danau tidak akan terus berlanjut. Menuru Appannagari (2017) bahwa manusia menjadi penyebab utama kerusakan menyeluruh pada atmosfir, air, tanah, berbagai elemen, dan ekosistim itu sendiri.

\section{SIMPULAN}

Nilai kualitas air di Danau Sentani berada di sebelah kanan nilai kapasitas asimilasi (-12.700 ton/bulan), hal ini menunjukkan bahwa danau Sentani telah tercemar oleh parameter TSS. Sedangkan, nilai kapasitas asimilasi parameter $\mathrm{PO}_{4}$ sebesar 44,36 ton/bulan dan sejak tahun 2016 danau Sentani tidak mampu melakukan self purification. Elemen kunci kendala - kendala pengendalian pencemaran danau Sentani di sub DAS Tlaga Ria yaitu Lemahnya Implementasi Regulasi lingkungan, Perbedaan tujuan antar stakeholder, Perbedaan tujuan antar wilayah administrasi, Lemahnya dukungan pemilik usaha, Konflik Kepentingan, dan Lemahnya Penegakan Peraturan. Kendala - kendala ini harus dihindari dan elemen - elemen kunci tersebut merupakan model pengendalian pencemaran di sub DAS Tlaga Ria.

Diperlukannya penelitian lanjutan untuk menganalisis Indek Pencemaran air, dan kapasitas asimilasi di seluruh DAS Sentani baik air danau, maupun sungai yang inlet ke Danau Sentani. Perlu juga kajian penelitian lanjutan tentang kondisi pencemaran pada tubuh ikan dan kesehatan masyarakat yang mengkonsumsi ikan di Danau Sentani.

\section{UCAPAN TERIMA KASIH}

Ucapan terima kasih disampaikan kepada Direktorat Riset dan Pengabdian Masyarakat Dikti serta LPPM Universitas Cenderawasih yang telah memberi dukungan hingga penelitian ini dapat berlangsung.

\section{DAFTAR PUSTAKA}

Andara, D., Haeruddin, R., \& Suryanto, A. (2014). Kandungan Total Padatan Tersuspensi, Biochemical Oxygen Demand dan Chemical Oxygen Demand serta Indeks Pencemaran Sungai Klampisan
Di Kawasan Industri Candi, Semarang. Jurnal of Maquares, 3(3), 177-187.

Appannagari, R.R., (2017). Environmental Pollution Causes And Cosequences: A Study. North Asian Journal of Social \& Humanities, 3(8), 151-155.

Badan Lingkungan Hidup Daerah Kabupaten Jayapura. 2016. Laporan Akhir Pemantauan Limbah Padat dan Kualitas Air Di Kabupaten Jayapura.

Bahteria, R., \& Jain, D., (2016). Water Quality Assesment of Lake: A Review. Journal Sustain. Water Resour. Manag, 2, 161-173, DOI 10.1007/s40899-015-0014-7.

Cheruiyot, C., \& Muhandiki, V., (2014). Review of Estimation of Pollution Load to Lake Victoria. Journal of Environmental and Earth Science, 4(1), 113-120.), https://doi.org/10.19044/esj.2014.v10n5p\%25p.

Darmasusantini, P., D., Merit, I., N., \& Dharma, I., G., B. (2015). Identifikasi Sumber Pencemar dan Analisis Kualitas air Tukad Saba Provinsi Bali. Jurnal Ecotrophic, 9(2), 57-63. https://doi.org/10.24843/EJES.2015.v09.i02.p10.

Duan, W., He, B., Nover, D., Yang, G., Chen, W., Meng, H., Zou, S., \& Liu, C. (2016). Water Quality Assemnent and Pollution Source Identification of the Eastern Poyang Lake Basin Using Multivariate Statistical Methods. Journal Sustainability, 8 (133), 1-15 Doi: 10.3390/su8020133.

Hamakonda, U., A., Suharto, B., \& Susanawati, L., D. (2019). Analisis Kualitas Air dan Beban Pencemaran Air Pada Sub DAS Boentuka Kabupaten Timor Tengah Selatan. Jurnal Teknologi Pertanian Andalas, 23(1), 56-67. https://doi.org/10.25077/jtpa.23.1.56-67.2019.

Kapisa, N., (2017). Kondisi Kenaikan Permukaan Danau Sentani 2016-2017. BPLH Propinsi Papua.

Lestiana, H., Mulyono, A., Maria, R., \& Mulyadi, D. (2019). Kesesuaian Lahan Berdasarkan Indeks Konservasi Secara Spasial di DAS Ciasem Hulu, Subang. Jurnal Limnotek Perairan Darat Tropis di Indonesia, 26(2), 119-129. http://dx.doi.org/10.14203/limnotek.v26i2.213.

Nugraheni C., T., Pawitan, H., Purwanto, Y., J., \& Ridwaansyah, I., (2019). Neraca Air Situ Cikaret dan Situ Kabantenan di Kabupaten Bogor Menggunakan Pemodelan Hidrologi SWAT. Jurnal Limnotek Perairan Darat Tropis Indonesia, $26(2)$, 89-102. http://dx.doi.org/10.14203/limnotek.v26i2.251.

Mahyudin, Soemarno, \& Prayogo, T.,R. (2015). Analisis Kualitas Air dan Strategi Pengendalian Pencemaran Air Sungai Metro di Kota Kepanjen Kabupten Malang. Jurnal PAL, 6(2), 105-114.

Marimin. (2004). Teknik dan Aplikasi Pengambilan Keputusan Kriteria Majemuk. Penerbit PT Gramedia Widiasarana Indonesia, Jakarta.

Patricia, C., \& Astono, W., H., D., I. (2018). Kandungan Nitrat dan Fosfat di Sungai Ciliwung. Proseding Seminar Nasional ke 4, ISSN (P): 2460- 
8696, ISSN (E) : 2540-7589, 179-189. http://dx.doi.org/10.25105/semnas.v0i0.3373.

Patty, S., Arfah, H., \& Abdul, M., S. (2015). Zat Hara (Fosfat, Nitrat), Oksigen terlarut dan $\mathrm{pH}$ Kaitannya dengan Kesuburan Di Perairan Jikumerasa, Pulau Buru. Jurnal Pesisir dan Laut Tropis, $1(1), 43-50$. https://doi.org/10.35800/jplt.3.1.2015.9578.

Pohan, D., A., S., Budiyono, \& Syafrudin. (2016). Analisis Kualitas Air Sungai Guna Menentukan Peruntukan Ditinjau dari Aspek Lingkungan. Jurnal Ilmu Lingkungan, 14(2), 63-71. https://doi.org/10.14710/jil.14.2.63-71.

Prasetia, A., \& Walukow, A.F. (2021). Analisis mutu air Danau Area Gelanggang Expo dengaan metode indeks pencemaran di kota Jayapura. Jurnal Dinamika Lingkungan Indonesia. 8(1), 4247. DOI 10.31258/dli.8.1.8(1),42-47.

Rahman, A., Alim, M., S., \& Utami, U., B., L. (2011). Inventarisasi dan identifikasi Sumber Pencemar Air Di Kota Banjarmasin. Jurnal EnviroScienteae, 7, 58-68.

Riza, F., Bambang, A., N., \& Kismartini, . (2015). Tingkat Pencemaran Lingkungan Perairan Ditinjau dari aspek Fisika, Kimia dan Logam di Pantai Kartini Jepara. Indonesian Journal Of Conservation, 4(1), 52-60. https://doi.org/10.15294/ijc.v4i1.5158.

Sentosa, A., A., Hedianto, D., A., \& Satria, H. (2017). Dugaan Eutrofikasi Di Danau Matano Ditinjau dari Komunitas Fitoplankton dan Kualitas Perairan. Jurnal Limnotek Perairan Darat Tropis di Indonesia, 24 (2), 61-73. http://dx.doi.org/10.14203/limnotek.v24i2.168.

Siombo, M. R. (2014). Tanggung Jawab Pemda Terhadap Kerusakan Lingkungan Hidup Kaitannya dengan Kewengan Perizinan Di Bidang Kehutanan dan Pertambangan. Jurnal Dinamika Hukum, Vol 14(3), 394-405. http://dx.doi.org/10.20884/1.jdh.2014.14.3.306

Skenderovic, I., Kalac, B., \& Becirovic, S., (2015). Environmental pollution and waste management. Balkan Journal of Health Sciences, 3 (1), 2-10.

Walukow, A.,F. (2008). Analisis Beban Pencemaran dan Kapasitas Asimilasi Danau Sentani, Papua Sebagai Upaya Konservasi Lingkungan Perairan. Jurnal Berita Biologi, Pusat Penelitian Biologi LIPI Bogor. ISSN 0126-1754, Volume 9 No 3, Desember 2008, 9(3).

https://doi.org/10.14203/beritabiologi.v9i3.777.
Walukow, A.,F. (2017b), Analysis of Pb Levels as Pollutant in the Waters of the Sentani Lake, Jayapura-Indonesia: Study of Determining Water Quality. Journal Der Pharma Chemica, 2017, 9(18),6-8.

Walukow, A.,F. (2017a). Analysis Of Polution On Physical - Chemical parameters and water environmental quality Index Using STORET index in Natural Tourism Park at Youtefa Bay, Jayapura Indonesia. Journal Der Pharma Chemica, 2017, 9(9), 8-12.

Walukow. A.,F. (2010a). Kajian Parameter Kimia Posfat Di Perairan Danau Sentani Berwawasan lingkungan. Jurnal Forum Geografi, Fakultas Geografi Universitas Muhamadiyah Surakarta. 24(2), 183-197. https://doi.org/10.23917/forgeo.v24i2.5025.

Walukow. A., F. (2010b). Penentuan Status Mutu Air Dengan Metode Storet Di Danau Sentani Jayapura Propinsi Papua. Jurnal Berita Biologi, Pusat Penelitian Biologi LIPI Bogor. ISSN 0126-1754, Volume $\quad 10 \quad$ No $3, \quad 277-281$. https://doi.org/10.14203/beritabiologi.v10i3.742.

Walukow. A.,F. (2010c). Analisis Kendala Pengelolaan Danau Sentani Berwawasan Lingkungan. Jurnal Limnotek Perairan Darat Tropis di Indonesia, 17(1), 118-127.

Walukow, A.,F. (2012). Analisis Kebijakan Penurunan Luas Hutan Di Daerah Aliran Sungai Sentani Berwawasan Lingkungan. Jurnal Manusia dan Lingkungan, 19(1), 74-84.

Walukow. A.,F. 2016. Analysis of metal concentrations of copper $(\mathrm{Cu})$ in water at sentani lake in jayapura - papua. Journal Der Pharmacia Lettre. 2016,8 (2),303-308.

Walukow, A., F. (2021a). Analisis Tingkat Pencemaran Air Di Kali Kampwolker Sebagai Inlet Ke Perairan Danau Sentani Dengan Menggunakan Metode Pollution Index. Jurnal Sains dan Teknologi, 10(1), 69-75.

Walukow, A.,F. (2021b). Analysis of Carrying Capasity and Water Pollution in the Simporo Strait Area After a Flash Flood. Ecological Engineering \& Environmental Technology. 22(3), 120-128. http://doi.org/10.12912/27197050/135528.

Yulius. (2016). Penataan Blok Cagar Alam Pegunungan Cycloop. BPDAS Mamberamo.

Zhao, Y., Yang, Z., \& Li, Y., (2010). Investigation of Water Pollution In Baiyangdian Lake, China. Journal Procedia Environmental Sciences, 2, 737748.

https://doi.org/10.1016/j.proenv.2010.10.085. 